\title{
Customers Perception Towards The Quality Of Services in Community Pharmacies in Amman-Jordan
}

\author{
Mohammad Farajat*, Jelnar Alkalaldeh, Ibrahim abu-hlaleh, Sana'a al sharari, \\ Neveen Elayan, Amjad Alyazjeen \\ Royal Medical Services, Pharmacy department, Amman-Jordan \\ *Correspondence author e-mail: redrockjordan10@gmail.com
}

\begin{abstract}
The purpose of this study was to measure customers perception towards the quality of services in community pharmacies in Amman-Jordan, through 30 community pharmacies were selected conveniently in Amman and were treated confidentially the quality of the services provided in these pharmacies was measured using the International Pharmaceutical Federation (FIP) working group standards by using face to face cross-sectional a questionnaire the Results revealed good perception toward these services, high compliance with stage 1 FIP standards. Females perception was higher than males. More work is needed by our community pharmacies on stages 2 and 3 standards in order to increase customer perception. Also the study show. In stage 1, the researcher's measurement was $79 \%$ lower than the pharmacist $(91 \%)$ with a difference of $(12 \%)$. In stage 2 the results were $66 \%$ and $76 \%$ respectively with a difference of $11 \%$ in measurement. In stage 3 the results were $62 \%$ and $70 \%$ respectively with a difference of $8 \%$.

On other hand we measure the customers perception of quality of services in these pharmacies by using adapted servqual scale, in convenient sample of 100 customers (52 female, 48 male) the results show a good perception by average of $76 \%$. (78\% female and $73 \%$ male), respectively. Implementation of online services and domiciliary services as well as participating in research projects and increasing the attention on behalf of Para pharmaceutical sections appeared to be useful.
\end{abstract}

Keywords: Perception. Customer. Community pharmacy. Service. Standards. Quality

\section{INTRODUCTION}

\section{Problem Statement}

In any health care system in the world, patients are considered the basic part of it (Tahir et al., 2012). And in order to achieve better patient outcomes, more focus is needed on the services provided to them; especially with the limited resources in health care system (Loewen et al., 2010).

As we know, pharmacists have a long history of providing health services to people, especially in the community pharmacy. And their traditional role has been replaced with a modified one, which needs a full range of skills in order to provide the optimum quality of care (Barber et al., 1994). The American Pharmacist Association (APA) reported that there is an expanding trend in pharmacy services, and more confidence in these services is increasing overtime. In spite of that, some studies considered pharmacists as healthcare professionals and business ones. (Wirth et al., 2011).

One of the important factors for improving health outcomes, is to enhance the interaction between patient and health care provider. (Tahir et al., 2012) 
A study performed in the united Arab emirates (UAE) revealed that pharmacists should search for new challenges in their pharmaceutical role in order to upgrade their efforts in healthcare system. (Al Akshar et al., 2014).

It is also important to study customers' perception towards pharmaceutical services, and to assess the satisfaction towards it as well. And that was noticed by the presence of a lot of qualitative and quantitative studies that measured the previous two criteria.

It is important to say that pharmacists have positive responses towards changes and developments in the healthcare services, (Barber et al., 1994). The good application of suitable pharmacy services, leads to higher profit and higher revenue of pharmacies. In addition to the improvement of professional roles (Swastini et al., 2013), it strengthens the relationship between customer satisfaction and the continuity of care (Tahir et al., 2012).

There are a few studies concerned in measuring the perception of customers or the satisfaction towards the quality of services provided in community pharmacies regarding our country.

\section{Problem background}

Many studies on patient perception and satisfaction have been performed on the worldwide scale, including different findings. In a quantitative study by (Tahir et al., 2012) using a questionnaire, the criteria of patient satisfaction are heterogeneous and there are no universal standards for this wide subject. But, in order to have better patient outcomes, the interaction between patients and healthcare providers should be enhanced. Three factors are important for patient satisfaction: time, access and behavior.
In Denspasar, a quantitative study is conducted by a questionnaire revealed that although the patients have a high consciousness and expectation for pharmaceutical services that must be provided for them, the perception of these services was the opposite (Swastini et al., 2013).

On the other hand, a quantitative study on community pharmacy services in Malta using self-administered questionnaire showed that, there is an overall positive perception of Maltese consumers towards community pharmacies, with the lowest satisfaction for the privacy of the pharmacy (Wirth et al., 2011).

In Benin City, a qualitative study was done in tertiary healthcare facility, using structured interview format on selected hypertensive outpatients. Poor services provided by pharmacists were rated regarding preventing or reducing health related problems. Although lower incidence of evolving health related problems is perceived by the patients when they met with the pharmacists. (Erah and Chuks-Eboka, 2008)

A quantitative study on Bangalore city in India, using a survey, found that a lot of efforts are needed to increase recognition of the public and the pharmacist regarding the services that must be provided through pharmacies (Jayaprakash et al., 2009).

The same result was found on patients by quantitative study in Pakistan using comprehensive questionnaire. Patients cannot realize their healthcare requirements from pharmacists and implementation of pharmaceutical care concept is required (Tahir et al., 2012).

Another qualitative study in Pakistan using face to face interview on community pharmacies established that because there was a shortage in the 
numbers of pharmacists available; the services provided were concentrated on pharmacies management instead of consumers, and as a result of that little consciousness regarding the role of pharmacists in the society (Azhar et al., 2013).

A study was performed by (Born et al., 2016) using cross sectional survey, there was an absence or deficiency in the recognition by patients towards services provided by pharmacies. And pharmacists have the role to teach and instruct patients about these services.

Using a combined observational qualitative study and quantitative questionnaire, pharmacists thought that they provided highly rated services in healthcare system, but more careful, detailed research is needed to value these services and correlate them with improving patient outcomes (Loewen et al., 2010).

And in order to motivate pharmacists to provide better pharmaceutical services, suitable fees can be obligated (Jayaparakash etal., 2009) (APA, 2015)

\section{Studies performed in Jordan}

A quantitative study on hospitals in Jordan found that physicians preferred traditional services rather than clinical ones (Tahaineh et al., 2009).Another quantitative study using a questionnaire found that the quality of health services provided by pharmacies affected patient perception, and there is an awareness for this correlation but not full satisfaction is achieved (Alsamydai and Baqer, 2015).

A quantitative study was performed by (Basbeti et al., 2014) using a questionnaire in Jordan, Iraq and the UAE. It combined the level of socioeconomic factors with the degree of dependence on the pharmacists regarding healthcare provided, and found that it is inversely related in Iraq and Jordan compared to the UAE.

So, modification of educational programmes are needed to meet patient requirements and to achieve their satisfaction, and this was revealed by a quantitative study on Jordanian hospitals using a questionnaire. It's stated that pharmacists perceived themselves having an important role in providing "medication reconciliation" services to patients, although low recognition regarding the presence of such policies (Hommour et al., 2016).

On the other hand, a qualitative case study by( Bulajeva, 2010) on one of the leading chain pharmacies in Jordan was performed; this community pharmacy was selected by the International Pharmaceutical Federation (FIP) community pharmacy section alongside with other different community pharmacies from different country in the world. One of the objectives is to see to what extent the arrangements placed in pharmacies join with the FIP service quality standards. Great attention was revealed for providing excellent customer services that improved customer satisfaction. And that was clear through the presence of standards of policies (SOP) that cover the services provided, like the presence of computerized operations, availability of enough numbers of pharmacists and wide opening hours, also the presence of the quality assurance department and the continuous education programmes. Because of all these variations in the health sector, many international organizations in the world have developed their own standards to control the pharmaceutical services and having better outcomes in the health sector as shown in table(1). 
One of the active non-governmental organizations in the pharmaceutical sector is the International Pharmaceutical Federation (FIP). In 1992, it established the first pharmacy service standards under the "Good Pharmacy Service GPP in Community and hospital pharmacy setting". In a collaboration with world health organization (WHO), the FIP/WHO joint document on good pharmacy practice (GPP) was issued in 1999. And significant improvement in health services provided by pharmacy sector was achieved since the adoption of these guidelines (FIP, 2012).

In this study, we adapted the standards developed by working group in the FIP to measure the quality of care in community pharmacy. According to the working group, these quality care standards provide a monitoring device for pharmacy services which leads to the prevention of any threats to society. These quality care standards are divided into three stages $(1,2,3)$, and stage (1) represents the minimum requirement that should be available in any community pharmacy (FIP, 2005).

\section{Statement of purpose}

The objective from this research is divided into two parts: first is to measure the customer perception towards the services provided in community pharmacy in Amman. Secondly is to measure the quality of services that is provided by selective community pharmacies in Amman, using the FIP working group standards.

\section{Hypothesis}

There is a positive relationship between customer perception and the quality of services provided in community pharmacies in Amman.

\section{Research Design}

\section{Participants}

The participants in this study are divided into two parts:
A) 100 customers were treated anonymously and were conveniently chosen from 30 community pharmacies that chosen in part B below. Males and females, English or Arabic spoken. Pregnant women and customers less than 18 years are excluded.
B) 30 community pharmacies were selected conveniently in Amman and were treated confidentially.

\section{Study design}

A) Measuring customer perception using face to face questionnaire over a period of 14 days. Around three customers were selected during their visit to the 30 pharmacies (in part B above) in Amman. Written informed consent was applied to every customer before filling the questionnaire. A pilot study was conducted on ten customers before the main study to test the reliability and validity of the instrument, fine adjustments were done.

B) Measuring the quality of services in 30 community pharmacies in Amman using face to face questionnaires over a seven-day period. To test for instrument reliability, a pilot study was conducted on five pharmacies. Written informed consent was applied on every pharmacy before the main study.

In each pharmacy, 2 questionnaires were filled, one by the researcher and the other one by the pharmacist as an audit process to ensure that the FIP quality care standards are followed.

\section{Data collection}

A) Customer perception questionnaire that is used in this study is adapted from servqual scale stated by 
Parasuraman et al,1991. The questionnaire is modified to comply with the presented cultural differences.

Servqual scale is composed of five dimensions and defined as the following:

1- Reliability: employees' ability to perform the requested services dependably and accurately. According to our questionnaire, it was measured by items number $(5,6,7,8)$.

2- Assurance: employees' ability to inspire trust and confidence. According to our questionnaire, it was measured by items number $(11,12,13,14,17$, 25).

3- Tangibles: Equipment, employees and physical facilities appearance ...etc.

According to our questionnaire, it was measured by items number $(1,2,3,4$, $15,21)$.

4- Empathy: Donation of caring and attention to every customer. According to our questionnaire, it was measured by items number $(22,23,20,19,18$, 16).

5- Responsiveness: Willingness to respond for the customers' requirements promptly. According to our questionnaire, it was measured by items number $(9,10,24)$.

Initially, the questionnaire was developed in English then was translated into Arabic. Then, this Arabic version was distributed on customers. The questionnaire is composed of 26 questions about perception of quality of service in community pharmacy. A likert type scale of five points was used to measure the perception (Strongly Disagree 1, Disagree 2, Neutral 3, Agree 4, Strongly Agree 5).
B) The quality service questionnaire is based on the standards of quality of care in the community pharmacy that is developed by the working group in FIP. No translation was done; the English version itself was distributed to the pharmacists in the selected community pharmacies. A likert type scale of five points was also used to measure the quality of service (Very poor 1, Poor 2, OK 3, Good 4, Very good 5).

The questionnaire is divided into 3 stages. According to the FIP, stage one represents the minimum requirements that must be available in every community pharmacy.

In Stage 1, areas included were: the setting of the pharmacy, handling of stock and preparation of medicines, provision of prescription medicines, supply of non- prescription medicines for self-care, interaction with patients and documentation system. While in Stage 2 were: equipment, health promotion activities, diagnostics, pharmacotherapy monitoring, research and professional development and auditing.

In Stage 3 areas included: domiciliary services, online services, preregistering training, Para pharmaceuticals and customer perception. In every area, there are numbers of domains, presented and measured.

\section{RESULTS}

All data are entered into Microsoft Excel version 2007 and analyzed.

Customer perception questionnaire:

Response rate was $100 \%$, demographic data are shown in table 1: 
Table 1. Customers Demographics

\begin{tabular}{|c|c|c|c|}
\hline \multirow{4}{*}{ Gender } & Character & $\mathbf{N}$ & $\%$ \\
\hline & Male & 45 & 48 \\
\hline & Female & 59 & 52 \\
\hline & Total & 94 & 100 \\
\hline \multirow{6}{*}{ Education } & No certificate & 4 & 4.3 \\
\hline & High school & 22 & 24 \\
\hline & Diploma & 5 & 5.4 \\
\hline & Bachelor Degree & 59 & 64.1 \\
\hline & Master/PhD & 2 & 2.2 \\
\hline & Total & 92 & 100 \\
\hline \multirow{6}{*}{ Age } & $18-25$ & 17 & 18 \\
\hline & $26-35$ & 41 & 44 \\
\hline & $36-45$ & 22 & 23 \\
\hline & $46-55$ & 11 & 12 \\
\hline & $>55$ & 3 & 3 \\
\hline & Total & 94 & 100 \\
\hline
\end{tabular}

Of the 100 customers (6 of them) didn't identify their gender. As shown in table1, our convenient sample composed of $48 \%$ males and $52 \%$ females.

For the education part, 8 customers didn't write their levels. Most of our customers had Bachelor Degrees
(64.1\%). Considering the age part, 6 customers didn't identify their age group. $44 \%$ of our convenient sample had age groups range between 26 to 35 years. Customer perception with items representing current pharmacy services using descriptive statistics as shown in table 2.

Table 2. Customer perception for the total sample and for gender wise

\begin{tabular}{|l|l|l|l|}
\hline Questionnaire Items & Male(N=48) & Female(N=52) & Total (N=100) \\
\hline $\begin{array}{l}\text { 1. The pharmacy provide } \\
\text { modern equipments and } \\
\text { adequate techniques in } \\
\text { providing its services }\end{array}$ & $74 \%$ & $74 \%$ & $75 \%$ \\
\hline $\begin{array}{l}\text { 2.Physical facilities are } \\
\text { visually appealing in the } \\
\text { pharmacy }\end{array}$ & $75 \%$ & $79 \%$ & $77 \%$ \\
\hline $\begin{array}{l}\text { 3.The employees of this } \\
\text { pharmacy are well dressed and }\end{array}$ & $79 \%$ & $80 \%$ & $80 \%$ \\
\hline
\end{tabular}




\begin{tabular}{|c|c|c|c|}
\hline Questionnaire Items & Male(N=48) & Female(N=52) & Total $(\mathrm{N}=100)$ \\
\hline \multicolumn{4}{|l|}{ neat in appearance } \\
\hline $\begin{array}{l}\text { 4.Visually appealing materials } \\
\text { associated with the service }\end{array}$ & $72 \%$ & $72 \%$ & $72 \%$ \\
\hline $\begin{array}{l}\text { 5.The employees of this } \\
\text { pharmacy show sincere interest } \\
\text { in solving patients' problems }\end{array}$ & $73 \%$ & $75 \%$ & $75 \%$ \\
\hline $\begin{array}{l}\text { 6.The pharmacy Provide the } \\
\text { pharmaceutical services from } \\
\text { the first time }\end{array}$ & $72 \%$ & $73 \%$ & $74 \%$ \\
\hline $\begin{array}{l}\text { 7.The employees of this } \\
\text { pharmacy provide services at } \\
\text { the time promised }\end{array}$ & $68 \%$ & $75 \%$ & $73 \%$ \\
\hline $\begin{array}{l}\text { 8.The employees of this } \\
\text { pharmacy inform customers } \\
\text { when services will be } \\
\text { performed }\end{array}$ & $70 \%$ & $72 \%$ & $71 \%$ \\
\hline $\begin{array}{l}\text { 9.The employee's in this } \\
\text { pharmacy offers prompt } \\
\text { services to customers if there is } \\
\text { need }\end{array}$ & $69 \%$ & $73 \%$ & $72 \%$ \\
\hline $\begin{array}{l}\text { 10.The employees of the } \\
\text { pharmacy are always willing to } \\
\text { help customers }\end{array}$ & $73 \%$ & $79 \%$ & $77 \%$ \\
\hline $\begin{array}{l}\text { 11.Employees attitude of the } \\
\text { pharmacy able to instill } \\
\text { confidence in customers }\end{array}$ & $74 \%$ & $79 \%$ & $78 \%$ \\
\hline $\begin{array}{l}\text { 12.Employees attitude in the } \\
\text { pharmacy fortify the feeling of } \\
\text { safety and privacy for } \\
\text { customers }\end{array}$ & $70 \%$ & $79 \%$ & $76 \%$ \\
\hline $\begin{array}{l}\text { 13. The employees of the } \\
\text { pharmacy are courteous at all } \\
\text { times }\end{array}$ & $76 \%$ & $81 \%$ & $79 \%$ \\
\hline $\begin{array}{l}\text { 14. The employees of the } \\
\text { pharmacy have the knowledge } \\
\text { and the ability to answer } \\
\text { customer question in good } \\
\text { manner }\end{array}$ & $75 \%$ & $78 \%$ & $77 \%$ \\
\hline $\begin{array}{l}\text { 15. The pharmacy has } \\
\text { convenient operating hours to } \\
\text { all customers }\end{array}$ & $74 \%$ & $79 \%$ & $77 \%$ \\
\hline
\end{tabular}




\begin{tabular}{|c|c|c|c|}
\hline Questionnaire Items & Male(N=48) & Female(N=52) & Total $(\mathrm{N}=100)$ \\
\hline $\begin{array}{l}\text { 16.The customer interest is the } \\
\text { main priority for the pharmacy }\end{array}$ & $70 \%$ & $81 \%$ & $76 \%$ \\
\hline $\begin{array}{l}\text { 17.The employees in the } \\
\text { pharmacy show respect and } \\
\text { kindness to customers }\end{array}$ & $77 \%$ & $83 \%$ & $80 \%$ \\
\hline $\begin{array}{l}\text { 18.The employees of the } \\
\text { pharmacy well understand } \\
\text { patients need }\end{array}$ & $73 \%$ & $78 \%$ & $76 \%$ \\
\hline $\begin{array}{l}\text { 19.The pharmacy offers } \\
\text { privacy for customers when } \\
\text { needed }\end{array}$ & $67 \%$ & $77 \%$ & $73 \%$ \\
\hline $\begin{array}{l}\text { 20.The pharmacy has good } \\
\text { diversity in products and } \\
\text { supplies }\end{array}$ & $72 \%$ & $76 \%$ & $75 \%$ \\
\hline $\begin{array}{l}\text { 21.The pharmacy is well } \\
\text { localized and provide adequate } \\
\text { parking lot }\end{array}$ & $72 \%$ & $76 \%$ & $74 \%$ \\
\hline $\begin{array}{l}\text { 22.The presence of female } \\
\text { pharmacist affect the quality of } \\
\text { services provided }\end{array}$ & $70 \%$ & $80 \%$ & $76 \%$ \\
\hline $\begin{array}{l}\text { 23.The presence of pharmacist } \\
\text { that understand the } \\
\text { alternatives for pharmaceutical } \\
\text { treatments affect the quality of } \\
\text { services }\end{array}$ & $73 \%$ & $80 \%$ & $77 \%$ \\
\hline $\begin{array}{l}\text { 24.Your acceptance about } \\
\text { waiting time in pharmacy }\end{array}$ & $76 \%$ & $81 \%$ & $79 \%$ \\
\hline $\begin{array}{l}\text { 25.The instructions related to } \\
\text { pharmaceutical treatments are } \\
\text { explained clearly }\end{array}$ & $76 \%$ & $81 \%$ & $79 \%$ \\
\hline $\begin{array}{l}\text { 26.In general, your satisfaction } \\
\text { about the quality of services in } \\
\text { the pharmacy }\end{array}$ & $78 \%$ & $82 \%$ & $81 \%$ \\
\hline
\end{tabular}

The percentages of customer perception were calculated for the total convenient sample $(\mathrm{N}=100)$ and the results were between (71\% and $80 \%)$. The highest perceptions $(80 \%)$ were for item number 3, (the employees in the pharmacy are well-dressed and neat in appearance); and for item 17 as well,
(.The employees in the pharmacy show respect and kindness to customers). The lowest perception $(71 \%)$ was for item number 8 in the questionnaire, (the employees of the pharmacy inform patients when services will be performed). As an overall evaluation(item number 26), 
customers' perceptions of the quality of services in the 30 community pharmacies were $81 \%$, and females had better perceptions towards these services than males $(82 \%<78 \%)$. Females perceptions towards the items in the questionnaire were between $72 \%$ (items numbers 4 and 8) and 83\% (item number 17).

On the other hand, Males' perceptions towards the items in the questionnaire were between $67 \%$ (item number 19) and $79 \%$ (item number 3 ).

In table 3 , the results of the five dimensions were recorded for both the total sample and gender wise. For the total sample, the highest result was for "Assurance Dimension(78\%)" and the lowest was for "Reliability Dimension $(73 \%)$.

Table 3. Measuring dimensions for the total sample and gender wise

\begin{tabular}{|l|l|l|l|}
\hline Dimension & Male(N=48) & Female(N=52) & $\begin{array}{l}\text { Total } \\
(\mathbf{N}=100)\end{array}$ \\
\hline Reliability & $71 \%$ & $74 \%$ & $73 \%$ \\
\hline Assurance & $75 \%$ & $80 \%$ & $78 \%$ \\
\hline Tangibles & $74 \%$ & $77 \%$ & $76 \%$ \\
\hline Empathy & $71 \%$ & $79 \%$ & $76 \%$ \\
\hline Responsiveness & $73 \%$ & $78 \%$ & $76 \%$ \\
\hline Average & $73 \%$ & $78 \%$ & $76 \%$ \\
\hline
\end{tabular}

For males, the highest score was $75 \%$ for assurance dimension, and the lowest one was $71 \%$ for reliability and empathy dimension. On the other hand, the highest score for females was for assurance dimension $80 \%$, and the lowest was for reliability dimension (74\%).

\subsection{Quality of service questionnaire}

The response rate was 94\%(two pharmacies rejected the filling of questionnaire). Demographic data are shown in table 4.

Table 4: Demographics data of the Pharmacist

Gender

\begin{tabular}{|l|r|l|l|}
\cline { 2 - 4 } Gender & Female & 21 & 70 \\
\cline { 2 - 4 } & Total & 30 & 100 \\
\hline \multirow{4}{*}{ Age } & $22-30$ & 19 & 63.33 \\
\cline { 2 - 4 } & $31-40$ & 7 & 23.33 \\
\cline { 2 - 4 } & $41-50$ & 4 & 13.33 \\
\cline { 2 - 4 } & Total & 30 & 100 \\
\hline
\end{tabular}


Zagazig J. Pharm. Sci. Jun, 2017

Vol. 26, Issue 1, pp, 13- 31

$30 \%$ of the pharmacists were males and the rest were females. About 64\% of the pharmacists had an age group between 22 to 30 years old, and $24 \%$
ISSN 23569786

ISSN (on-line) 2356_9786

had and age group between 31 to 40 years old. In table 5 below the results of the domains are recorded:

Table 5: Quality of service Domains

\begin{tabular}{|c|c|c|c|}
\hline Domain & $\begin{array}{l}\text { Measurement } \\
\text { by the } \\
\text { Researcher }\end{array}$ & $\begin{array}{l}\text { Measurement } \\
\text { by the } \\
\text { Pharmacist }\end{array}$ & $\begin{array}{l}\text { Differences In } \\
\text { measurement } \\
\text { Pharmacist - } \\
\text { researcher) }\end{array}$ \\
\hline $\begin{array}{l}\text { Stage } 1 \\
\text { Setting of the pharmacy } \\
\text { 1) Appearance of the pharmacy }\end{array}$ & $85 \%$ & $94 \%$ & $9 \%$ \\
\hline 2) Accessibility of the pharmacy & $83 \%$ & $93 \%$ & $10 \%$ \\
\hline 3) Window dressing & $83 \%$ & $92 \%$ & $9 \%$ \\
\hline 4) Dispensing area & $82 \%$ & $89 \%$ & $7 \%$ \\
\hline $\begin{array}{l}\text { 5) Counseling area/ pharmacist } \\
\text { consultation area }\end{array}$ & $79 \%$ & $85 \%$ & $6 \%$ \\
\hline 6) Staffing & $81 \%$ & $95 \%$ & $14 \%$ \\
\hline $\begin{array}{l}\text { Handling of stock and preparation of } \\
\text { medicine } \\
\text { 7) Purchasing of stock }\end{array}$ & $79 \%$ & $88 \%$ & $9 \%$ \\
\hline 8) Storage of stock & $79 \%$ & $89 \%$ & $10 \%$ \\
\hline $\begin{array}{l}\text { 9) Maintain of quality of stock } \\
\text { (identification of expired } \\
\text { products, recalled medication) }\end{array}$ & $80 \%$ & $93 \%$ & $13 \%$ \\
\hline $\begin{array}{l}\text { 10) Availability of standards } \\
\text { operating procedures for } \\
\text { extemporaneous dispensing }\end{array}$ & $75 \%$ & $84 \%$ & $9 \%$ \\
\hline $\begin{array}{l}\text { 11) Documentation } \\
\text { extemporaneous operation }\end{array}$ & $65 \%$ & $73 \%$ & $8 \%$ \\
\hline 12) Storage of raw material & $55 \%$ & $67 \%$ & $12 \%$ \\
\hline $\begin{array}{l}\text { Provision of prescription medicine } \\
\text { 13) Prescription receipt and patient } \\
\text { identification }\end{array}$ & $83 \%$ & $94 \%$ & $11 \%$ \\
\hline 14) Prescription checking & $83 \%$ & $96 \%$ & $13 \%$ \\
\hline $\begin{array}{l}\text { 15) Provision of information on the } \\
\text { use of medication(s) }\end{array}$ & $84 \%$ & $95 \%$ & $11 \%$ \\
\hline
\end{tabular}




\begin{tabular}{|c|c|c|c|}
\hline Domain & $\begin{array}{l}\text { Measurement } \\
\text { by the } \\
\text { Researcher }\end{array}$ & $\begin{array}{l}\text { Measurement } \\
\text { by the } \\
\text { Pharmacist }\end{array}$ & $\begin{array}{l}\text { Differences In } \\
\text { measurement } \\
\text { Pharmacist - } \\
\text { researcher) }\end{array}$ \\
\hline 16) Dispensing of medication & $84 \%$ & $97 \%$ & $13 \%$ \\
\hline $\begin{array}{l}\text { Supply of nonprescription medicine } \\
\text { for self care } \\
\text { 17) Advice on the selection of } \\
\text { medicine }\end{array}$ & $84 \%$ & $99 \%$ & $15 \%$ \\
\hline $\begin{array}{l}\text { 18) Advice on the use of non } \\
\text { prescription medicines }\end{array}$ & $83 \%$ & $98 \%$ & $15 \%$ \\
\hline 19) Responding to minor ailments & $83 \%$ & $97 \%$ & $14 \%$ \\
\hline $\begin{array}{l}\text { Interaction with patients } \\
\text { 20) Communication skills (verbal } \\
\text { and non verbal message)of } \\
\text { pharmacists and pharmacy } \\
\text { staff }\end{array}$ & $85 \%$ & $97 \%$ & $12 \%$ \\
\hline $\begin{array}{l}\text { 21) Provision of advice on the safe } \\
\text { use of medicine and on the } \\
\text { management of disease } \\
\text { condition }\end{array}$ & $81 \%$ & $95 \%$ & $14 \%$ \\
\hline 22) Promotion of good health & $82 \%$ & $96 \%$ & $14 \%$ \\
\hline $\begin{array}{l}\text { 23) Provision of written } \\
\text { information (labels, leaflets) }\end{array}$ & $82 \%$ & $97 \%$ & $15 \%$ \\
\hline $\begin{array}{l}\text { Documentation systems } \\
\text { 24) Patient medication profiles }\end{array}$ & $71 \%$ & $81 \%$ & $10 \%$ \\
\hline 25) Formulary system & $69 \%$ & $78 \%$ & $9 \%$ \\
\hline $\begin{array}{l}\text { 26) Policies and standard operating } \\
\text { procedure }\end{array}$ & $68 \%$ & $81 \%$ & $13 \%$ \\
\hline $\begin{array}{l}\text { 27) Documentation of pharmacist } \\
\text { interventions }\end{array}$ & $65 \%$ & $79 \%$ & $14 \%$ \\
\hline $\begin{array}{l}\text { Stage } 2 \\
\text { Equipment } \\
\quad \text { 28) Cleanliness and good state }\end{array}$ & $84 \%$ & $93 \%$ & $9 \%$ \\
\hline 29) Routine maintenance/validity & $83 \%$ & $93 \%$ & $10 \%$ \\
\hline $\begin{array}{l}\text { 30) Availability of refrigerator, } \\
\text { counting device, and other } \\
\text { dispensing equipment }\end{array}$ & $85 \%$ & $95 \%$ & $10 \%$ \\
\hline 31) Reference during information & $77 \%$ & $89 \%$ & $12 \%$ \\
\hline
\end{tabular}




\begin{tabular}{|c|c|c|c|}
\hline Domain & $\begin{array}{l}\text { Measurement } \\
\text { by the } \\
\text { Researcher }\end{array}$ & $\begin{array}{l}\text { Measurement } \\
\text { by the } \\
\text { Pharmacist }\end{array}$ & $\begin{array}{l}\text { Differences In } \\
\text { measurement } \\
\text { Pharmacist - } \\
\text { researcher) }\end{array}$ \\
\hline systems (e.g. pharmacopoeia) & & & \\
\hline $\begin{array}{l}\text { Health promotion activities } \\
\text { 32) Distribution of leaflets }\end{array}$ & $75 \%$ & $88 \%$ & $13 \%$ \\
\hline $\begin{array}{l}\text { 33) Display of health promotion } \\
\text { advertisements }\end{array}$ & $67 \%$ & $83 \%$ & $16 \%$ \\
\hline $\begin{array}{l}\text { 34) Participation in health } \\
\text { promotion campaigns }\end{array}$ & $66 \%$ & $81 \%$ & $15 \%$ \\
\hline $\begin{array}{l}\text { Diagnostics } \\
\text { 35) Provision of diagnostic tests } \\
\text { e.g., blood pressure } \\
\text { monitoring, blood cholesterol } \\
\text { testing, monitoring of peak } \\
\text { expiration flow rate, urinalysis } \\
\text { and pregnancy testing, body } \\
\text { weight monitoring }\end{array}$ & $53 \%$ & $59 \%$ & $6 \%$ \\
\hline $\begin{array}{l}\text { 36) Documentation of diagnostic } \\
\text { tests carried out }\end{array}$ & $43 \%$ & $49 \%$ & $6 \%$ \\
\hline $\begin{array}{l}\text { Pharmacotherapy monitoring } \\
\begin{array}{l}\text { 37) Development } \\
\text { pharmaceutical care plans }\end{array}\end{array}$ & $79 \%$ & $87 \%$ & $8 \%$ \\
\hline 38) Patients monitoring & $77 \%$ & $89 \%$ & $12 \%$ \\
\hline $\begin{array}{l}\text { 39) Identification of medication } \\
\text { related problems }\end{array}$ & $79 \%$ & $90 \%$ & $11 \%$ \\
\hline 40) Interaction with prescriber & $75 \%$ & $90 \%$ & $15 \%$ \\
\hline $\begin{array}{c}\text { Research and } \\
\text { development } \\
\begin{array}{c}\text { 41) Participation } \\
\text { projects }\end{array}\end{array}$ & $42 \%$ & $52 \%$ & $10 \%$ \\
\hline 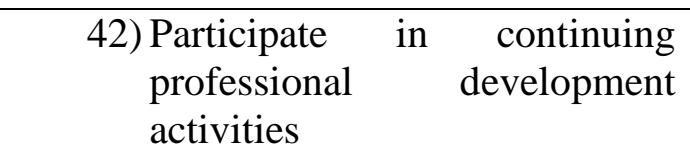 & $43 \%$ & $56 \%$ & $13 \%$ \\
\hline $\begin{array}{l}\text { Audit } \\
\text { 43) Development of quality } \\
\text { manuals for the pharmacy } \\
\text { system }\end{array}$ & $76 \%$ & $86 \%$ & $10 \%$ \\
\hline
\end{tabular}




\begin{tabular}{|c|c|c|c|}
\hline Domain & $\begin{array}{l}\text { Measurement } \\
\text { by the } \\
\text { Researcher }\end{array}$ & $\begin{array}{l}\text { Measurement } \\
\text { by the } \\
\text { Pharmacist }\end{array}$ & $\begin{array}{l}\text { Differences In } \\
\text { measurement } \\
\text { Pharmacist - } \\
\text { researcher) }\end{array}$ \\
\hline $\begin{array}{l}\text { 44) Running audit exercises for } \\
\text { services provided }\end{array}$ & $72 \%$ & $81 \%$ & $9 \%$ \\
\hline $\begin{array}{l}\text { Stage } 3 \\
\text { Domiciliary services } \\
\text { 45) Provision of pharmaceutical } \\
\text { services to house bound } \\
\text { persons, nursing home }\end{array}$ & $33 \%$ & $31 \%$ & $-2 \%$ \\
\hline 46) Procedures & $29 \%$ & $31 \%$ & $2 \%$ \\
\hline $\begin{array}{l}\text { Online services } \\
\text { 47) Provision of online pharmacy } \\
\text { services }\end{array}$ & $60 \%$ & $69 \%$ & $9 \%$ \\
\hline $\begin{array}{l}\text { 48) System maintenance and } \\
\text { update }\end{array}$ & $57 \%$ & $67 \%$ & $10 \%$ \\
\hline 49) Handling requests & $52 \%$ & $65 \%$ & $13 \%$ \\
\hline 50) Website & $39 \%$ & $51 \%$ & $12 \%$ \\
\hline $\begin{array}{l}\text { Pre-registration training } \\
\text { 51) Acceptance of pre-registration } \\
\text { trainees }\end{array}$ & $76 \%$ & $85 \%$ & $9 \%$ \\
\hline $\begin{array}{l}\text { 52) Monitoring and documentation } \\
\text { requirement }\end{array}$ & $71 \%$ & $81 \%$ & $10 \%$ \\
\hline $\begin{array}{l}\text { 53) Activity description for } \\
\text { trainees }\end{array}$ & $69 \%$ & $80 \%$ & $11 \%$ \\
\hline $\begin{array}{l}\text { Para pharmaceuticals } \\
\text { 54) Availability of medical } \\
\text { devices, homeopathic products, } \\
\text { and other Para pharmaceutical } \\
\text { and no pharmaceutical items }\end{array}$ & $79 \%$ & $87 \%$ & $8 \%$ \\
\hline 55) Display of Para pharmaceutical & $76 \%$ & $85 \%$ & $9 \%$ \\
\hline $\begin{array}{l}\text { 56) Information } \\
\text { pharmaceutical }\end{array}$ & $79 \%$ & $87 \%$ & $8 \%$ \\
\hline $\begin{array}{ll}\text { Over all compliance with the } & \begin{array}{l}\text { whands } \\
\text { standard }\end{array}\end{array}$ & $83 \%$ & $89 \%$ & $6 \%$ \\
\hline
\end{tabular}

\section{Stage 1 (Domains):}


The measurements of the researcher were between (85\%) for domains 1 and 20 (Appearance of the pharmacy and Communication skills) respectively and $55 \%$ for domain 12(storage of raw materials). Pharmacist measurements were between $99 \%$ for domain 17 (Advice on the selection of medicine) and $67 \%$ for domain 12 (storage of raw material) which was consistent with the researcher perception. The differences in the measurements of domains between the pharmacist and the researcher were (-6\% to $15 \%)$.

\section{Stage 2 (Domains):}

The measurements of the researcher were between $85 \%$ for domain number 30 (availability of fridges), and $42 \%$ for domain number 41(Participation in research projects). For the pharmacists measurements, results were between $95 \%$ and $49 \%$ for domains 30 and 36 (Availability of refrigerator and Documentation of diagnostic tests carried out) respectively. The differences in the measurements between the pharmacist and the researcher were (6\% to 16$)$.

\section{Stage 3 (Domains):}

The researcher's measurements were highest with $79 \%$ for domains number 54(availability of medical devices and ...etc.) and domain number 56 (information on Para pharmaceuticals), and the lowest with $29 \%$ for domains number 46. For pharmacists' measurements, the highest score of $87 \%$ was for domain number 54 and 56 and the lowest of $31 \%$ was for domains numbers 45 and 46. Differences in measurements between the pharmacist and the researcher were between $(-2 \%$ to 13$)$.

In table 6 below, the results for areas included in the measurement of quality of services were recorded. For stage 1: The area of supply of non-prescription medicines for self-care had the highest score by the researcher and pharmacist measurement (83\% and $98 \%$ respectively).

Documentation system area had the lowest scores by the researcher and the pharmacist measurements $(80 \%$ and $68 \%$ respectively). The differences in measurements between the researcher and pharmacist were between $(9 \%$ and $15)$.

For stage 2, the equipment area had the highest score by the researcher and the pharmacist measurement (82\%, 93\% respectively). Research and professional development area and diagnostic area had the lowest scores (54\% and $43 \%$ respectively). The differences in measurements were $(6 \%$ and $151 \%$ ).

For stage 3: Para pharmaceutical area had the highest scores by the researcher and the pharmacist $(72 \%$, $86 \%$ respectively). Domiciliary service area had the lowest score (31\% for both). The differences in the measurements were between (zero and 14). The overall quality of service measurements were recorded in Table 7.

Table 6: Areas included in the measurement of quality of service. 


\begin{tabular}{|c|c|c|c|}
\hline Areas included & Researcher & $\begin{array}{l}\text { Pharmacist } \\
(\mathrm{N}=30)\end{array}$ & $\begin{array}{l}\text { Differences } \\
\text { In } \\
\text { measurement }\end{array}$ \\
\hline Stage 1 & & & \\
\hline Setting of the pharmacy & $82 \%$ & $91 \%$ & $9 \%$ \\
\hline $\begin{array}{l}\text { Handling of stock and preparation of } \\
\text { medicine }\end{array}$ & $72 \%$ & $82 \%$ & $10 \%$ \\
\hline provision of prescription medicine & $84 \%$ & $96 \%$ & $12 \%$ \\
\hline $\begin{array}{l}\text { supply of nonprescription medicine for } \\
\text { self care }\end{array}$ & $83 \%$ & $98 \%$ & $15 \%$ \\
\hline interaction with patient & $83 \%$ & $96 \%$ & $13 \%$ \\
\hline documentation system & $68 \%$ & $80 \%$ & $12 \%$ \\
\hline $\begin{array}{l}\text { Stage } 2 \\
\text { Equipment }\end{array}$ & $82 \%$ & $93 \%$ & $11 \%$ \\
\hline Health promotion activities & $69 \%$ & $84 \%$ & $15 \%$ \\
\hline Diagnostic & $48 \%$ & $54 \%$ & $6 \%$ \\
\hline Pharmacy monitoring & $78 \%$ & $89 \%$ & $11 \%$ \\
\hline $\begin{array}{lll}\begin{array}{l}\text { Research } \\
\text { development }\end{array} & \text { and } & \text { professional }\end{array}$ & $43 \%$ & $54 \%$ & $11 \%$ \\
\hline Audit & $74 \%$ & $84 \%$ & $10 \%$ \\
\hline $\begin{array}{l}\text { Stage } 3 \\
\text { Domiciliary service }\end{array}$ & $31 \%$ & $31 \%$ & $0 \%$ \\
\hline Online service & $52 \%$ & $63 \%$ & $11 \%$ \\
\hline Pre-registration training & $72 \%$ & $82 \%$ & $10 \%$ \\
\hline Para pharmaceuticals & $72 \%$ & $86 \%$ & $14 \%$ \\
\hline
\end{tabular}

Table7: Overall quality of service measurements

\begin{tabular}{|l|l|l|l|}
\hline Stages & Researcher & $\begin{array}{l}\text { Pharmacist } \\
\text { (N=30) }\end{array}$ & $\begin{array}{l}\text { Differences } \\
\text { In measurement }\end{array}$ \\
\hline Stage 1 & $79 \%$ & $91 \%$ & $12 \%$ \\
\hline Stage 2 & $66 \%$ & $76 \%$ & $11 \%$ \\
\hline Stage 3 & $62 \%$ & $70 \%$ & $8 \%$ \\
\hline
\end{tabular}

In stage 1, the researcher's measurement was $79 \%$ lower than the pharmacist $(91 \%)$ with a difference of $(12 \%)$. In stage 2 , the results were $66 \%$ and $76 \%$ respectively with a difference of $10 \%$ in measurement. 
Zagazig J. Pharm. Sci. Jun, 2017

Vol. 26, Issue 1, pp, 13- 31

In stage 3, the results were $62 \%$ and $70 \%$, respectively with a difference of $8 \%$.

\section{DISCUSSION}

In the present study, the mean level of customer perception was found to be good. On the other hand, the overall satisfaction was rated very good by the customers. By analyzing each item in the customer perception survey, no significant differences were seen between the items. To improve patient perception, more concentration on the reliability and responsiveness of the service provided must be done. And this can practically applied by informing customers when their services will be performed, and offering prompt services (items number 8 and 9).

The perfect employees' appearance and their best interest in their customers in our community pharmacies contributed positively in the customer perception of the service provided. Females' perceptions were higher than males towards the community pharmacy services, and this might be due to several factors. The most important one was the cultural factor and this was obviously revealed by item number 22 (the presence of a female pharmacist affects the quality of service).

Moreover, females are more sensitive and emotional than men and this was shown by higher perception for items considering and confidence (item 11), feeling safe (item 12) and privacy (item 19). And this result was powered with the empathy dimension finding in this study; where the empathy dimension recorded the highest difference between males and females among all dimensions.

Assurance dimension of the customer perception survey plays an important role in the study. So, the employee in the pharmacy is the backbone for the optimum services provided to customers. And this is might due to our position in third world countries where there is over reliance on
ISSN 23569786

ISSN (on-line) 2356_9786

employees for providing the services, because of the shortness of new communication tools and supplies. This result was with the finding of (Bashiti et al., 2014).

In order to correlate the perception of our customers with the real services provided (as we noted in the introduction), the measurement of the quality of services were required with an auditing process as explained previously. As we found in our study, this good perception of the customer towards the pharmaceutical services is due to high compliance with "stage 1

standards" (minimum standards) which was confirmed by both the researcher and the pharmacist. And this was correlated with the finding of (Bulajeua, 2010).

As a matter of fact, more work should be done on stages two and three standards in order to get excellent patient perception. Considering stage 2, both of the researcher and the pharmacist have low compliance with the Research and Professional Development standards, especially for the provision of Participation in research projects. In addition, this affected customers' perceptions of the prompt services in the "needed cases (item 9)" and the community pharmacist efforts to solve different health problems (item 5). Also reflected in the low compliance regarding the research professional standards discovered by the researcher and the pharmacist; it also affected item number 5 in customer perception survey. On the other hand, the high compliance with health promotion activity standards that were measured by the researcher and the pharmacist, especially for the distribution of leaflet domains, proportionally affected the perception of the customers towards the adequate knowledge of the employee and his/her ability to answer heath related questions (item 14).

Regarding stage 3 of the community standards, low compliance for domiciliary services founded by the researcher and the 
pharmacist affected negatively the perception of the customers towards the prompt services provided in the needed cases, (item9). The compliance of online services standards, especially the presence of a website for the pharmacy was also low. This reflected on lowering perception concerning privacy (item9) and adequate working hours to satisfy the customers (item15). Eventually, we make an evidence for our hypothesis that there is a positive relationship between customer perception and the quality of services provided in the community pharmacies. And the result of this study complies with the finding of (Alsamyai and Baqer, 2015) about this positive correlation.

\section{Limitation}

The first limitation of this study that the samples of the customers and the pharmacies were convenient; so generalization couldn't have been done. Also, the sample size must have been increased for both of the customers and the pharmacies in order to achieve better results.

Another limitation was for the quality of services survey, that the study was in cross-sectional design. It is preferably better to convert it to longitudinal one. The most important limitation in this study was the short time available to complete the surveys and analyze them as well.

\section{Conclusion}

Since patient perception is integral part in sustainability of healthcare services, the goal of this study is to assess customer perception towards the quality of services in selective community pharmacies in Amman. As shown in the discussion and the results above, customers' perceptions were good. And this is correlated in this study by higher compliance with stage 1 FIP standards found by the researcher and the pharmacist. However, in order to increase customer perception, more work is needed by our community pharmacies on stages 2 and 3 of FIP standards. Our community pharmacies should develop a new trend and make a great change in providing health services, in order to close the gap between the old techniques used in our developing countries and the modern ones used in developed countries. Consequently, this can be done by introducing online services and domiciliary services as well as participating in research projects and increasing the attention on behalf of Para pharmaceutical sections.

\section{REFERENCES}

Al Samydai, A., Baqer, A. (2015). Measuring patient satisfaction regarding the quality of health care service provided by pharmacist. International Journal of Medicine and Pharmaceutical Science, 5 (6), 71-84.

Al Akshar, S., Metwaly, Z., and Shamssain, M. (2014). Patient perceptions of community pharmacy practice in the UAE. An overview IOSR. Journal of Pharmacy, 4 (11),8-14.

Azhar, S., Hassali, M., Taha, A., Khan, S., Murtaza, GH., Hussain, I. (2013) Evaluation of the perception of community pharmacists regarding their role in Pakistan's health care system: A qualitative approach. Tropical Journal of pharmaceutical research, 12 (4), 635-639.

Barber, N., Smith, F., \& Anderson, S. (1994). Improving quality of health care: the role of pharmacist. Quality in health care, 3, 153-158.

Basheti, I., Quanaibi, T., Hamadi, S., AbuGharbieh, T., Saleh, S., Aburuz, S., Mahmoud, M., Bulatova, N. (2014). Patient perspectives of the community pharmacist in the Middle East: Jordan, The UAE \& Iraq. 
Zagazig J. Pharm. Sci. Jun, 2017

Vol. 26, Issue 1, pp, 13- 31

Pharmacology \& Pharmacy, 5, 588599.

Born, A., Pinto, SH., Patel, A. Khuder, S.,and Vaidya, V. (2016). Patient awareness, perceived benefit, and intent to participate in pharmacy services. Innovations in pharmacy, 7 (3): Article 10

Bulajeva , A. (2010). Pharmaceutical health care services and quality management community pharmacies. An International study. University of Helsinki. Finland

Erah, PO., Chuks-Eboka, NA, (2008). Patient perception of the benefits of pharmaceutical care services in the management of hypertension in a tertiary health care facility in Benin City. Tropical Journal of Pharmaceutical Research, 7 (1), 897-905.

Good pharmacy practice (2012). Joint FIP/WHO. Guideline on GPP: Standard for quality of pharmacy services.

Good pharmacy practice guidelines. (2002). Indian Pharmaceutical Association.

Good Pharmacy Practice (GPP) in community and hospital pharmacy setting, (1996). World Health Organization.

Hammour, KA., R, Farha., \& I, Basheti. (2016) Hospital pharmacy medication reconciliation practice in Jordan, perceptions and barriers. J Eval Clin pract, 22(6), 932-937.

Jayaprakash, G., Rajan, M., \& Shivam, P. (2009). Consumer view of community pharmacy services in Bangalore City. India. Pharmacy practice, 7 (3), 157-162.

Loewen, P., Merrett, F., \& De Lemos, J. (2010). Pharmacist's perception of
ISSN 23569786

ISSN (on-line) 2356_9786

the impact of care they provide. Pharmacy practice, 8 (2), 89-95.

Model standards of practice for Canadian pharmacists. (2009). The National Association of pharmacy regulatory Authorities (NAPRA).

Parasuraman, A., Berry, L., Zeithmal, (1991). Retirement and reassessment of the servqual scale. Journal of Retalining, Winter 1991, pp. 420-50.

Pharmacist improving patient access to health care. (2015). American pharmacist Association.

Professional standards for hospital pharmacy services: optimizing patient outcomes from medicine. (2014). The Royal pharmaceutical society.

Quality care standards in community pharmacy, (2005). International Pharmaceutical Federation.

Safe effective pharmacy practice: Competence. (2011). Pharmacy Council of New Zealand.

Standards of practice for clinical pharmacies, (2014). American College of clinical pharmacy (ACCP).

Standards of practice: community. (2006). The Manitoba pharmacies Association.

Standards for the operation of licensed pharmacies, (2011). Alberta College of pharmacists.

Standards of pharmacy operation community pharmacy, (2015). New found land and Larador Pharmacy Board.

Swatini, D., Wahyudhana, G., \& Udayana A., N. (2013). The comparison between patients perception and expectation on pharmacy services in Denpasar. International Journal of 
Pharmacy teaching and practices, 4 (2), 670-675.

Tahaineh, L., Wazaify, M., AlbsoulYounes, A., Khader, Y., \& Zaidan, M. (2009). Perceptions, experiences, and expectations of physicians in hospital settings in Jordan regarding the role of the pharmacists. Research in social and administrative pharmacy, 5, 63-70.

Tahir, M., Nawaz, Sh., Zaka Butt, M., Amin, F., \& Mahmood, KH. (2012). In patient perceptions, Needs, Expectation and satisfaction within tertiary care settings. Journal
ISSN (on-line) 2356_9786

sciences and research, 4 (12), 20252031.

The pharmaceutical society of Northern Irelands standards for registered pharmacy premises. (2010). The pharmaceutical society of Northern Irelands.

Wirth, F., Tabone, F., Azzopardi, L., Gauci, M., Zarb-Adami, M., and Serracino-inglott, A. (2011). Consumer perception of the community pharmacist and community pharmacy services in Malta. Journal of Pharmaceutical Health Services Research.

$$
\begin{aligned}
& \text { مدى إدر الك المستهلكين لجودة الخدمات المقدمة في الصيدليات في الأردن-عمان } \\
& \text { كحم فرجات ، جلنار الكلالدة ، إبراهيم ابو هلالة ، سناء الثراري ، نيفين العليان ، امجد العبادي. }
\end{aligned}
$$

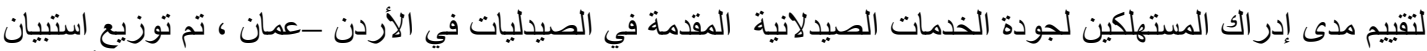

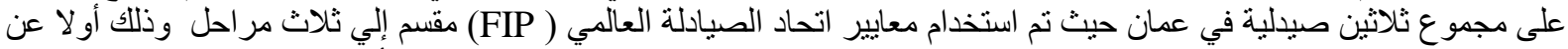

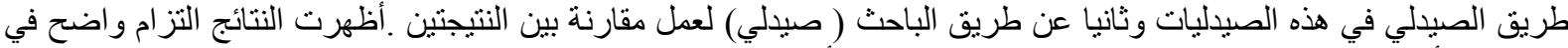

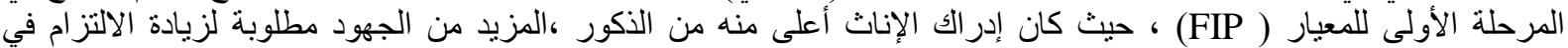

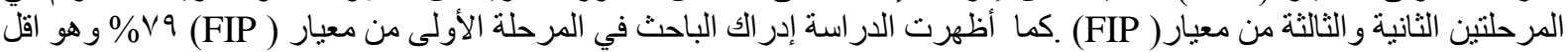

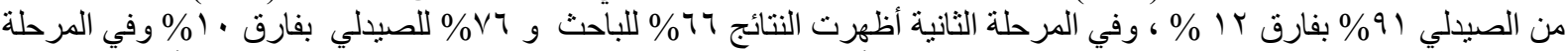

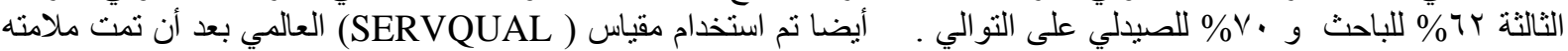

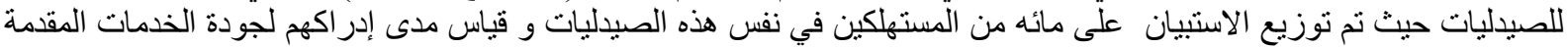

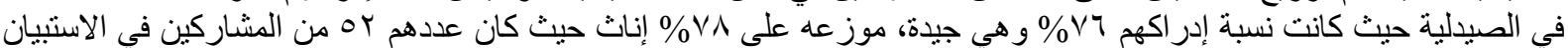

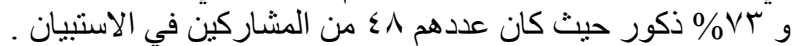

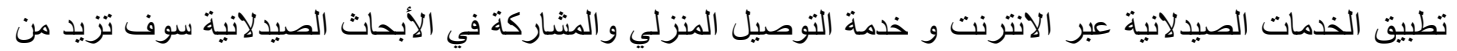

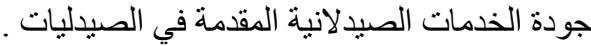

